\title{
Extendable Board Game to Facilitate Learning in Supply Chain Management
}

\author{
Linda William ${ }^{* 1}, Z^{\prime}$ 'Aba Bin Abdul Rahim ${ }^{1}$, Robert de Souza ${ }^{1}$, Eko Nugroho ${ }^{2,3,4}$, Rio Fredericco ${ }^{2}$ \\ ${ }^{1}$ The Logistics Institute Asia Pacific, National University of Singapore, 21 Heng Mui Keng Terrace \#04-01, Singapore 119613 \\ ${ }^{2}$ Kummara Studio, Jl. Sidomukti no. T1, Bandung 40123 Indonesia \\ ${ }^{3}$ Center for Research on Information \& Communication Technology, Institute Technology Bandung, Jl. Ganesha No.10, Lb. \\ Siliwangi, Coblong, Kota Bandung, Jawa Barat 40132, Indonesia \\ ${ }^{4}$ GameLab, Computer Science Program, Bina Nusantara University, Joseph Wibowo Center Campus, Jl. Hang Lekir I No. 6 Senayan, \\ Jakarta 10270, Indonesia
}

\begin{tabular}{l} 
A R T I C L E I N F O \\
\hline Article history: \\
Received: 14 June, 2018 \\
Accepted: 08 July, 2018 \\
Online: 23 July, 2018 \\
\hline Keywords: \\
Game-based learning \\
Facilitate learning \\
Supply chain management \\
Board game \\
Expandable framework
\end{tabular}

\section{Introduction}

This paper is an extension of work originally presented in 2017 IEEE 6th International Conference on Teaching, Assessment, and Learning for Engineering (TALE) [1]. It focuses on developing and evaluating an extendable board game as a game-based learning framework to facilitate teaching and learning in Supply Chain Management (SCM).

Game-based learning has been introduced to improve training activities and initiatives by stimulating learning engagement and motivation through role playing and repeatability for the players to

\begin{abstract}
A B S T R A C T aing processes in various fields, including supply chain management (SCM). Most of these games are specifically designed to focus on certain scenarios and concepts. For example, the original beer distribution game focuses on a single product supply chain without considering capacity and process reliability into account. This creates challenges for extending the games to cover other concepts in SCM. To tackle this problem, we propose a board game, titled ThinkLog, as a face-to-face extendable framework to facilitate learning in SCM. It can be extended to generate different scenarios for various concepts in SCM without changing the basic game structure. Using this principle, we have extended the basic version of ThinkLog to two other scenarios, namely: humanitarian logistics and urban logistics, by simply modifying the rule of the game. Each scenario would have different learning objectives embedded in the gameplay. The game is also complemented with a computer-based application (digital application) to enhance the overall learning experience and collect relevant data (data gathering) during a game session. These three scenarios have been evaluated on four-interactive sessions with government officials and policy-makers in Indonesia. Each session has been consistent in its acceptance of the game as a tool to facilitate learning in SCM, regardless of the scenarios that we played. Our learning objective evaluation also shows that the game is effective in deepening the players' understanding of SCM concepts.
\end{abstract}

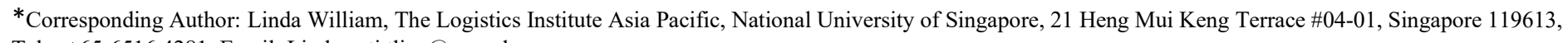
Telp: +65-6516 4281, Email: Lindawati.tliap@nus.edus.ag

learn new skills and concept voluntarily $[2,3,4,5,6]$. It is a subset of serious games which includes the use of any medium of games (e.g. board games, card games, sports or digital games) for learning purposes [7]. It has been implemented in various fields, such as healthcare $[8,9,10]$, military applications [11], city planning [12] and supply chain management $[13,14,15,16,17]$.

Previous studies have identified the benefits of these type of games in a variety of critical-contexts [3]. It includes enhancing engagement and motivation, improving self-monitoring, recognizing and solving problems, improving decision making, and developing social skills for collaboration and negotiation [3, 


\section{William et al. / Advances in Science, Technology and Engineering Systems Journal Vol. 3, No. 4, 99-111 (2018)}

$18,19]$. It would advance the players' understanding and learning in a scientific knowledge [20]. By using games, players become more involved in solving multiple tasks or challenges. Games provide a hand-on experience where the players need to plan appropriate strategies based on their knowledge and skills, implement these strategies in the experimented environment and respond to the consequences of their strategies. It would promote players' motivation and knowledge transfers in a subsequent realistic context [20,21].

However, most of the game-based learning in SCM focus on one or a limited number of scenarios. For example, the original beer distribution game is designed for a pure retail distribution game without taking product conversion, capacity and process reliability into account [22] or the blood supply chain only focuses on perishable goods [23]. It cannot be extended (or difficult to be extended) to cover different SCM concepts without changing the game structure or game components. Hence, it is limiting the implementation of the games.

Recognizing this problem, we propose a board game, titled ThinkLog, as an extendable face-to-face learning framework for SCM concept. It uses role-playing and simulation to stimulate discussion and interaction between the players. It creates a safe environment for the players to share their thoughts and practice their new skills without the threat of real-world consequences. ThinkLog can be extended to generate different scenarios for various concepts in SCM without changing the basic game structure. To demonstrate its capability, we have extended the basic scenario of ThinkLog [1] to cover two more complex SCM concepts, namely: humanitarian logistics and urban logistics. These new concepts can be embedded in the game by modifying the rules of the game.

We also develop a digital companion application to complement our board game. Companion apps have been used in several games, such as Dungeon Master's Assistance for Dungeons and Dragon game [24] and smart play system for Yes or Know board game [25], to guide the players during the game and provides a simple calculation for fastening the game processes. Our companion app aims to enhance the overall learning experience and collects the relevant data (data gathering) during a game session. The data collected can be analyzed further to understand the players' behavior and game experience. Using this insight, we would be able to adjust and customize the game to fit with individual learning behavior.

To evaluate the effectiveness of ThinkLog, we conducted four interactive sessions with government officials and policy makers in Indonesia using different scenarios. From those sessions, we learnt that the game (with or without the companion app) is highly accepted by the players. The players were also able to grasp the learning objectives of the game easily. Other than these four sessions, we also conducted a game session with master students in the National University of Singapore, as part of their SCM course, to evaluate the game in a larger group setting. The game acceptance and learning objective evaluation of the players resonates throughout the game session.

The remaining of the paper will be organized as follows: Section 2 presents the literature review and section 3 presents the proposed board game. Section 3 includes the game design, components, scenarios and its companion app. Section 4 discusses the evaluation method to measure the effectiveness of ThinkLog in facilitating learning in SCM. Section 5 reviews ThinkLog adjustment for adoption in classroom with large group setting and Section 6 presents the conclusions and future research direction.

\section{Literature Review}

In this section, relevant literature in the areas of board games and games for SCM are reviewed.

\subsection{Board Games}

Board games have been used as entertainment for centuries, starting from the ancient games such as Go and Backgammon that are still used today [26]. Generally, board games are played using an artwork [27] which incdice the main board, balls, dices, and cards. It has a set of rules that need to be obeyed by all the players. Points or rewards are given according to the rules. The players have a flexibility to change the rules based on the consensus from all the players [25]. They would take turns to play and receive feedbacks immediately. The actions and feedbacks are all apparent to all the players. The players would also be able to discuss with each other openly.

Although it has not been explored extensively as digital games, board games show promising opportunities to facilitate learning and training [28, 29, 30]. It has been proven to be as effective as digital games to facilitate learning [31]. As part of game-based learning, board games are able to enhance the players' engagement and motivate them to learn new skills, including social skills, to get potential rewards from the game through interaction and discussion with other players. It can stimulate the players' ability to think and solve problems and challenges. The nature of board games also implies transparencies and interactions as the core mechanism of the game. Hence, these board games are suitable for collaborative games where all players need to work together as a team to win the game [29] or other similar contexts which highly depend on real human interaction [28].

Board games have been successfully implemented to support learning and training in healthcare [32]. It shows a significant increment of knowledge on nutrition labeling [31], dengue hemorrhagic fever [32], healthy eating [33], chronic disease and risk factors [34], tooth morphology [35], pediatric [36], and cancer treatment [37]. Other than healthcare, board games have also been implemented in urban planning [38], agriculture [39], and software design [40]. The Beer Distribution Game, a well-known game in $\mathrm{SCM}$, is also available on board game version $[13,41]$.

\subsection{Games for $S C M$}

A number of games have been introduced to facilitate learning of Supply Chain Management (SCM) concepts [6], among which are the famous Beer Distribution Game [13, 42, 43], Blood Supply Chain Game [23, 44], Mortgage Service Game [15] and Distributor Game $[16,17]$.

The beer distribution game is the most well-known game in SCM and part of many SCM curriculum since it was being developed by MIT in the 1960s [43]. There are several variants of the beer distribution game in the literature, these includes the stationary beer game [14], computer simulated beer game (e.g. [45, 46]) and online beer game [42]. This game aims to introduce the 


\section{William et al. / Advances in Science, Technology and Engineering Systems Journal Vol. 3, No. 4, $99-111$ (2018)}

basic concepts of the bullwhip effect and the benefits of information sharing and lead-time reduction. It simulates a supply chain for a single product involving a four-level supply chain composed of a retailer, a wholesaler, a distributor and a manufacturer. Each player takes one role and for each turn, he/she follows the same set of activities, that is to fulfil customer demand, order from supplier, and manage inventories. The goals of this game are to minimize the total holding and backorder costs incurred in the entire supply chain.

Blood Supply Chain Game demonstrates supply and demand balance in healthcare perishable products with limited shelf life and production. It simulates the simplified supply chain of blood units from donors to patients based on a real case study modelling the UK blood supply chain [23]. This game is played from the perspective of the distributor which is the middle-player in the blood supply chain network. It has different game options and parameters to determine the probability of blood supply and demand and fulfillment policy. Each player aims to maximize the number of order fulfillment to the hospitals by considering the limited stock.

Different from beer distribution game and blood supply chain game that focus on a supply chain with finished goods inventory, Mortgage Service Game is intended to teach service-oriented SCM concepts [15] that typically do not hold any inventory and can only manage backlogs through capacity adjustment (such as number of employee's adjustment). It aims to introduce the bullwhip effect resulting from information and capacity adjustment lags and impact of end-user demand information in the service industry. This game represents a simplified mortgage approval process that has four stages, namely: initial processing, credit checking, surveying and title checking. Each player or team of players controls a particular stage and able to adjust its capacity by hiring or firing employees to check all mortgage applications in its backlog for each turn. Depending on the setup, the other stages may be managed by artificial agents or real players. The game also introduces lags on the capacity adjustment processes. The goal of this game is to minimize the total cost for the entire supply chain, resulting from employee salaries and service delays (certain fine or backlog fee would be added to the total cost).

Lastly, distributor game, is operating at a continuous clock with ongoing events and responses to individual decision to mimic the real-time global supply chain [17]. It is different from the other three games where the players need to wait for their turns to make their actions. Distributor game is a specific instance of Global Supply Chain Game (GSCG). It aims to educate the players on critical leadership skills for global supply chain in real time. These skills include strategic leadership, operations management, financial management and information technology.

Table 1. SCM Game Comparison

\begin{tabular}{|c|c|c|c|c|c|}
\hline Category & $\begin{array}{c}\text { Beer Distribution } \\
\text { Game }\end{array}$ & $\begin{array}{c}\text { Blood Supply Chain } \\
\text { Game }\end{array}$ & $\begin{array}{c}\text { Mortgage Service } \\
\text { Game }\end{array}$ & Distributor Game & ThinkLog \\
\hline \multicolumn{6}{|l|}{ Game world } \\
\hline Type & $\begin{array}{l}\text { Role-playing } \\
\text { simulation }\end{array}$ & $\begin{array}{l}\text { Role-playing } \\
\text { simulation }\end{array}$ & $\begin{array}{l}\text { Role-playing } \\
\text { simulation }\end{array}$ & $\begin{array}{l}\text { Role-playing } \\
\text { simulation }\end{array}$ & $\begin{array}{l}\text { Role-playing } \\
\text { simulation }\end{array}$ \\
\hline Platform & Board, Digital, Online & $\begin{array}{l}\text { Board, Digital } \\
\text { (Excel-based) }\end{array}$ & Digital & Online & Board \\
\hline $\begin{array}{l}\text { Technical } \\
\text { Features }\end{array}$ & $\begin{array}{l}\text { Multi players with } \\
\text { four roles; } \\
\text { Players wait for their } \\
\text { turn to make their } \\
\text { actions }\end{array}$ & $\begin{array}{l}\text { Single player from } \\
\text { the perspective of } \\
\text { distributor }\end{array}$ & $\begin{array}{l}\text { Single player/multi } \\
\text { players; } \\
\text { Players wait for } \\
\text { their turn to make } \\
\text { their actions }\end{array}$ & $\begin{array}{l}\text { Single player; } \\
\text { Players do not need } \\
\text { to wait for their turn } \\
\text { to make their } \\
\text { actions }\end{array}$ & $\begin{array}{l}\text { Multi players; } \\
\text { Players wait for } \\
\text { their turn to make } \\
\text { their actions }\end{array}$ \\
\hline \multicolumn{6}{|l|}{ Game Event } \\
\hline $\begin{array}{l}\text { Subject or } \\
\text { content } \\
\text { areas }\end{array}$ & $\begin{array}{l}\text { Industrial production } \\
\text { and distribution } \\
\text { system }\end{array}$ & $\begin{array}{l}\text { Supply and demand } \\
\text { balance for } \\
\text { perishable goods }\end{array}$ & $\begin{array}{l}\text { Service-oriented } \\
\text { SCM }\end{array}$ & Global supply chain & $\begin{array}{l}\text { Supply Chain } \\
\text { Management }\end{array}$ \\
\hline Scenario & $\begin{array}{l}\text { One scenario; } \\
\text { Single product in a } \\
\text { four level supply } \\
\text { chain }\end{array}$ & $\begin{array}{l}\text { One scenario; } \\
\text { Blood supply chain }\end{array}$ & $\begin{array}{l}\text { One scenario; } \\
\text { Mortgage approval } \\
\text { process that has } \\
\text { four stages }\end{array}$ & $\begin{array}{l}\text { One scenario; } \\
\text { A four-level global } \\
\text { supply chain }\end{array}$ & $\begin{array}{l}\text { Expendable to } \\
\text { different scenarios } \\
\text { with different } \\
\text { gameplay }\end{array}$ \\
\hline $\begin{array}{l}\text { Learning } \\
\text { objective }\end{array}$ & $\begin{array}{l}\text { Introduce the basic } \\
\text { concepts of the } \\
\text { bullwhip effect and } \\
\text { the benefits of } \\
\text { information sharing } \\
\text { and lead-time } \\
\text { reduction }\end{array}$ & $\begin{array}{l}\text { To improve } \\
\text { understanding of } \\
\text { complex principles } \\
\text { of supply chain for } \\
\text { perishable goods }\end{array}$ & $\begin{array}{l}\text { Introduce bullwhip } \\
\text { effect resulting } \\
\text { from information } \\
\text { and capacity } \\
\text { adjustment lags and } \\
\text { impact of end-user } \\
\text { demand } \\
\text { information in the } \\
\text { service industry }\end{array}$ & $\begin{array}{l}\text { To learn leadership } \\
\text { skills that are } \\
\text { critical to manage } \\
\text { real-time global } \\
\text { supply chain. }\end{array}$ & $\begin{array}{l}\text { Different scenarios } \\
\text { would have } \\
\text { different learning } \\
\text { objectives }\end{array}$ \\
\hline
\end{tabular}




\section{William et al. / Advances in Science, Technology and Engineering Systems Journal Vol. 3, No. 4, 99-111 (2018)}

All players take a role as a distributor in a distribution center in a four level supply chain. Other levels, including competing distributors are played by artificial agents to create a complex and dynamic global environment.

The summary and comparison of these four games and our proposed board game are presented in Table 1. The comparison is based on game categories adapted from [47]. Other than these four games, there are other games designed to illustrate different SCM concepts (see, for example, Lean Leap Logistics Game [48] and The Chain Game [49]).

\section{ThinkLog: An Expandable Learning Framework}

This section would describe ThinkLog as a special board game designed to enable the extension in the scenarios without changing the basic game structure. The game design, components, scenarios and companion app are reviewed.

\subsection{Game Design}

As an interactive board game for game-based learning, ThinkLog is carefully designed to balance the entertainment components and the pedagogy (i.e. learning objectives and outcomes). The game needs to have a clear objective, derived from specific SCM concepts, research outcomes and case studies. It also needs to have a clear pedagogy to influence learning and motivate the players to gain specific knowledge and skills related to the learning objectives. However, the game would also need to maintain the enjoyment and fun components, such as fantasy [50, 51], challenge [52, 53], choice [54], mechanism and playability [55]. It enables the players to engage and immerse into the game which would eventually motives the players to achieve new skills and understands new concepts voluntarily in a greater speed.

To balance these factors, ThinkLog is developed by following the game base learning framework [56], as illustrated in Figure 1. The framework has been adapted to include board game elements, such as interaction between the players. For each scenario, specific concepts are translated to the learning objectives and then converted into the specific scenario with clear goals for the players.

The entertainment components are captured by the game characteristics that allow players to be involved and engaged in the game. The characteristics can be categorized into 6 criteria, namely: challenge [52, 53], choice [54], competition, fantasy $[50,51]$, goal, and rule [57]. The summary of these characteristics is shown in Table 2 .

\subsection{Game Components}

There are four main components of ThinkLog, namely: main board, demand cards, gameplay/rules and game master. These are essential components to play ThinkLog regardless of the scenarios played.

\subsubsection{Main board}

ThinkLog's main board is a symmetrical map to visualize actions and responses during the game. It is a center of the whole activities in the game. It is also the base for all the engagements and twists during the game. By design, the board serves as a platform that gives players a (pseudo) control of the entire game environment. This sense of control is important to keep the player focus and bring more excitement to the game. The board also shows the player' actions and (action) feedbacks.

To represent the supply chain network and logistics activities, several nodes for the players' logistics facilities or other logistics assets are included. Depending on the game scenarios, the players may be able to determine their facility locations. Logistics activities will occur on the map between these facilities. Common disruptions such as traffic congestions, flooding and facilities' breakdown can be shown in the main board to introduce risk and uncertainty aspects of the supply chain.

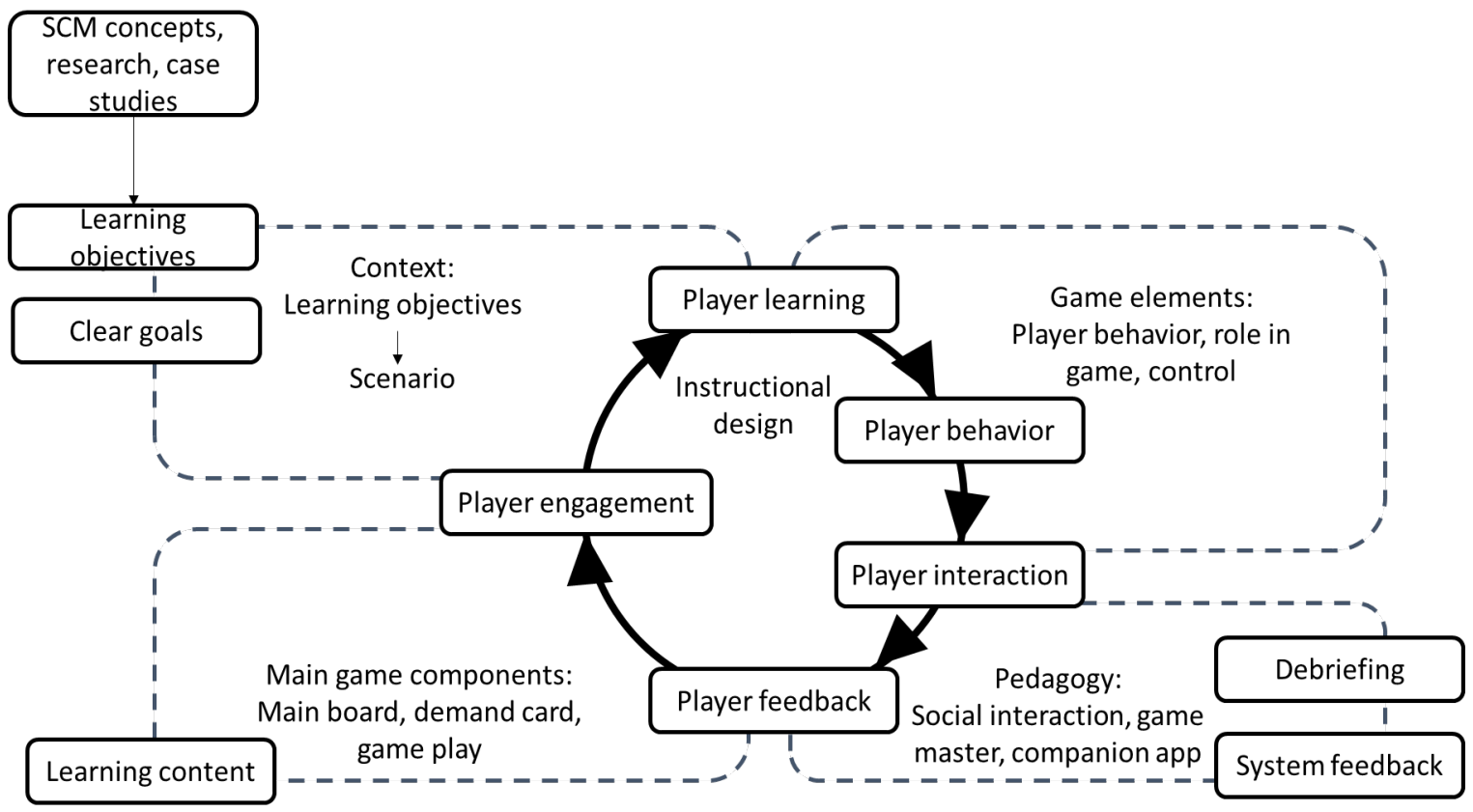

Figure 1. ThinkLog Game Design 
Table 2. ThinkLog Characteristics

\begin{tabular}{|c|c|}
\hline Cha & $\begin{array}{l}\text { - The difficulty level is determined by the } \\
\text { lead time and demand level. } \\
\text { - Various disruptions (such as traffic } \\
\text { congestions, flooding and facilities' } \\
\text { breakdown) would be added. }\end{array}$ \\
\hline Cho & $\begin{array}{l}\text { - Depending on the scenarios, the players } \\
\text { may need to decide the locations of their } \\
\text { facilities and consolidate their orders. } \\
\text { - Players need to select their vehicle's } \\
\text { delivery route. } \\
\text { - Players need to decide the number of goods } \\
\text { to ship to the next level node in the supply } \\
\text { chain and the number of goods to order } \\
\text { from the previous level node in the supply } \\
\text { chain }\end{array}$ \\
\hline Con & $\begin{array}{l}\text { - Depending on the scenarios, the players } \\
\text { may compete with the other players to win } \\
\text { the game. } \\
\text { - The players may compete to get the highest } \\
\text { performance (in term of money or other } \\
\text { points) }\end{array}$ \\
\hline Fantasy & $\begin{array}{l}\text { The game uses the main board and other } \\
\text { components (i.e. vehicles) to help the players } \\
\text { imagine the logistics environment. }\end{array}$ \\
\hline $\begin{array}{l}\text { Goal (Game } \\
\text { Objective) }\end{array}$ & $\begin{array}{l}\text { The general goal is to create an efficient } \\
\text { supply chain network. }\end{array}$ \\
\hline Rule & $\begin{array}{l}\text { - Each player needs to wait for his/her turns } \\
\text { to take actions. } \\
\text { - Interaction between players and game } \\
\text { master are encouraged. }\end{array}$ \\
\hline
\end{tabular}

There are two variations of the main board depending on the point or node locations as shown in Figure 2. The first variation, named basic main board, has eight facility locations, while the second variation, named flexible main board, has several alternative locations where the players can choose to locate their facilities or assets.

\subsubsection{Demand cards}

During the game, players will be introduced to "Demand Cards", as shown in Figure 3. It represents the market demands that need to be fulfilled during the game and players can either work together or individually to do so. The demand values are dependent on the scenarios; it can be randomly generated or based on a certain distribution to mimic real demands for a particular good in the particular scenario.

\subsubsection{Gameplay}

The gameplay core mechanic in ThinkLog is point to point delivery where the players need to deliver a certain amounts of goods to a certain point. Players main objective is to develop a strategy for efficient and effective deliveries which include managing their delivery timing, amounts, and resupplying their stocks. It will determine the result of the game and players' performance in the game.

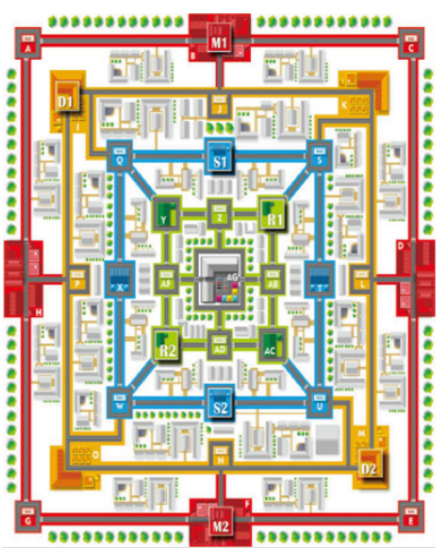

(a) Basic Main Board with fixed warehouse locations

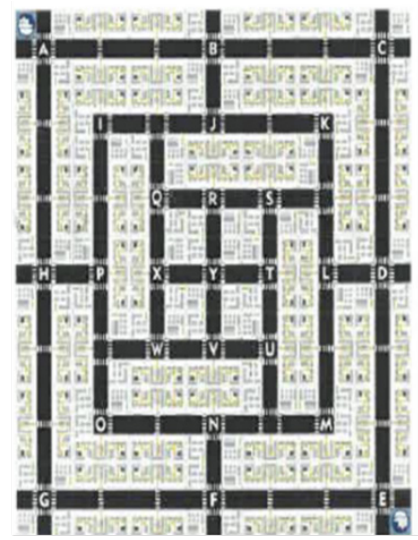

(b) Flexible Main Board with alternative warehouse's locations
Figure 2. ThinkLog Main Board

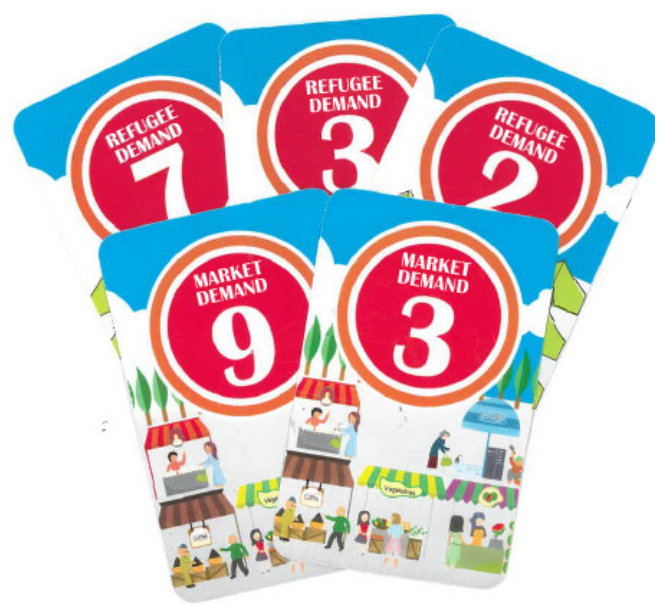

Figure 3. ThinkLog Demand Cards

To develop their delivery strategies, the players must consider the following criteria: locations, management cost, facilities and vehicle constraints, and supply availability. Tweaking these criteria would create different situations in the game and eventually resulting in different scenarios. There are 3 main activities for the players within a round of the game as follows.

1. Ship. The players send the exact amount of goods ordered by the next level node in the supply chain (i.e. the player's customer). If the players do not have enough goods and cannot fulfil all the order, they will get a backlog token.

2. Pay. The players pay inventory cost and backlog cost (if any).

3. Order. The players give order to the previous level in the supply chain (i.e. the player's supplier) and pay the price. 


\section{William et al. / Advances in Science, Technology and Engineering Systems Journal Vol. 3, No. 4, 99-111 (2018)}

The 3 main activities can be re-arranged and adjusted if needed in specific scenarios.

\subsubsection{Game Master}

A game master guides the overall gameplay of the game session and ensures players understand and follow the rules accordingly. Depending on the number of players and the game master's availability, the game session may be led by one main game master and several supporting/group game masters. For each game session, the game master would need to do the following:

1. Briefing. The game master initiates a discussion highlighting on: 1) the concept of the game and its relations with the logistics/supply chain topic; and 2) the overview of the game rules and objectives to guide the players on how to play the game.

2. Playing. The game master would be involved in the game, by:

- Observing the group dynamics.

- Providing some additional information/motivation to make sure all participants actively involved in the session.

- Intervening the game in case there are some (unwanted) conflicts. The game master may take necessary action to minimize any possible risk of distraction.

3. Debriefing. The game master conducts a discussion after the game session. The game master would motivate the players to share their experience and highlighting some learning points that they found during the playing phase. Later the game master summarizes those findings by emphasizing on main learning points of the game.

Other than these four main components, there are other components for ThinkLog game. It includes player board, truck token, facility token, good token, congestion token, paper money and order form. Some scenarios may need additional components. The use of these components is also depending on the scenarios played. Several components can be replaced by a feature in the companion app. For example, paper money can be replaced by virtual money in the companion app.

\subsection{ThinkLog Scenarios}

There are 3 scenarios of ThinkLog that have been developed, namely: basic, humanitarian logistics and urban logistics. The two later scenarios are the extensions of the basic scenario. Each scenario is designed to accommodate a certain theme and focuses on different learning objectives. The basic scenario focuses on information flow and coordination challenge in supply-chain and logistics sector. At the same time, it provides an overview of risk management in supply chain and the bullwhip effect. The second scenario focuses on introducing the Multi Criteria Decision Making (MCDM) procedure [58, 59] and its implementation in a simplified humanitarian logistics setting. And the third scenario focuses on important aspects of facility management in the context of last mile delivery. A summary of these scenarios is presented in Table 3.

\subsubsection{Basic Scenario}

Similar to the Beer Distribution Game [13, 42, 43], each player would choose one out of four available roles, namely: manufacturer, distributor, wholesaler, or retailer. Each role represents one level in the overall supply chain network. Each player or a team of players (2-3 players per team) will take the role of a supply chain coordinator and is responsible in managing their goods, supplies and facilities to fulfil the demand from their customers (or the next level in the supply chain). The learning points for the basic scenario are bullwhip effect, lead time, and stock management. The game can be played by 4 to 10 players for approximately 90-120 minutes.

\subsubsection{Humanitarian Logistics Scenario}

The humanitarian logistics scenario adapts Multi Criteria Decision Making (MCDM) concept to determine the locations of the warehouses/distribution centers for relief supply stocks in humanitarian setting [60]. MCDM is a structured framework to analyze decision problems that involve complex multiple objectives $[58,59]$. It can be used to accommodate complex decision processes involving various criteria and various decision makers with different viewpoints.

For this scenario, players are divided into different teams. Each team represents an expert team of regulators in humanitarian disaster relief. Their aim is to provide a continuous delivery of relief goods to the disaster area. To do so, each team first need to determine the optimal location for their warehouse and later to optimize their operation (delivery). Failure to deliver the required relief goods at the right time would be penalized with a failure token for the team. The team with the least failure token at the end of the game is the winner. The game can be played by 6-10 players with 60-90 min duration of play.

The game is divided into two stages, namely: preparation and respond stage. In the preparation stage, the players need to decide the optimal warehouse location(s) by MCDM methodology by considering a list of decision criteria, described in [60]. While in the respond stage, the players need to deliver the goods to the main disaster area. The game play at this stage is similar to the basic scenario.

\subsubsection{Urban Logistics Scenario}

Urban logistics scenario focuses on last mile deliveries in urban areas. It has four different roles, namely: port, distributor, wholesaler and retailer. Ideally, the game should be played by 8 players where 1 player as the port, 2 players as distributors, 2 players as wholesalers and 3 players as retailers. Each player is competing with each other to optimize their logistics activities.

This scenario has two stages, namely: preparation and respond stage. Similar to humanitarian logistics scenario, in the preparation stage, the players (except for the port) need to decide the optimal warehouse location(s) using MCDM methodology. But, the criteria used are different from the humanitarian logistics scenario. On the respond stage, the players need to deliver the goods to their customers. It is similar to the basic scenario, with the following differences: 1) the demand locations are random for each round and scattered all over the map; 2 ) each 
Table 3. ThinkLog Scenarios

\begin{tabular}{|c|c|c|c|}
\hline \multirow{3}{*}{$\begin{array}{l}\text { Learning } \\
\text { objective }\end{array}$} & \multicolumn{3}{|c|}{ ThinkLog } \\
\hline & Basic scenario & \multirow{2}{*}{\begin{tabular}{|l|} 
Humanitarian logistics scenario \\
- To introduce the concept of Multi \\
Criteria Decision Making (MCDM) \\
for selecting warehouse location for \\
relief supply stocks in humanitarian \\
logistics
\end{tabular}} & \multirow{2}{*}{\begin{tabular}{|l} 
Urban logistics scenario \\
- To introduce MCDM for selecting \\
warehouses/collection and delivery \\
points (CDP) and last-mile \\
challenges in urban distribution
\end{tabular}} \\
\hline & $\begin{array}{l}\text { - To provide an overview of } \\
\text { information flow and coordination } \\
\text { challenges in supply chain and } \\
\text { logistics } \\
\text { - To introduce the bullwhip effect }\end{array}$ & & \\
\hline \multicolumn{4}{|c|}{ Game components } \\
\hline Main board & Basic main board & Basic main board & Flexible main board \\
\hline Demand card & $\begin{array}{l}\text { Demand card shows the demand } \\
\text { value }\end{array}$ & Demand card shows demand value & $\begin{array}{l}\text { Demand card shows demand value } \\
\text { and demand location. } \\
\text { Note: demand locations are scattered } \\
\text { and dispersed all over the map. }\end{array}$ \\
\hline Gameplay & 1 stage & $\begin{array}{l}2 \text { stages, namely: } \\
\text { - } \quad \text { preparation stage (to determine } \\
\text { the warehouse location) } \\
\text { - } \begin{array}{l}\text { respond stage (to deliver certain } \\
\text { amount of relief goods to the } \\
\text { main disaster area) }\end{array} \\
\end{array}$ & $\begin{array}{l}\text { 2 stages, namely: } \\
\text { - } \text { preparation stage (to determine } \\
\text { the warehouse location) } \\
\text { - } \begin{array}{l}\text { respond stage (to deliver certain } \\
\text { amount of goods to the urban } \\
\text { area) }\end{array}\end{array}$ \\
\hline Roles & $\begin{array}{l}4 \text { roles, namely: manufacturer, } \\
\text { distributor, wholesaler, and retailer }\end{array}$ & $\begin{array}{l}1 \text { roles: regulator in humanitarian } \\
\text { disaster relief }\end{array}$ & $\begin{array}{l}4 \text { roles, namely: port, distributor, } \\
\text { wholesaler, and retailer }\end{array}$ \\
\hline \multirow[t]{4}{*}{$\begin{array}{l}\text { Relation } \\
\text { between roles }\end{array}$} & Mroduce( () & & Receive goods $\bigcirc$ \\
\hline & order $\mid$ ship & & order $\mid$ ship \\
\hline & Wholesaler & & Wholesaler \\
\hline & $\underset{\text { Demand Cards }}{\operatorname{demand}} \uparrow||_{\text {fulfil }}$ & & $\underset{\text { Demand Cards }}{\operatorname{demand} \uparrow \mid \text { fulfil }}$ \\
\hline \multicolumn{4}{|l|}{ Game setup } \\
\hline $\begin{array}{l}\text { Number of } \\
\text { players }\end{array}$ & 4-10 players & 6-10 players & 4-8 players \\
\hline Game duration & 90-120 minutes/session & $60-90$ minutes & $60-90$ minutes \\
\hline $\begin{array}{l}\text { Performance } \\
\text { measurement }\end{array}$ & Remaining money and backlogs & $\begin{array}{l}\text { Remaining money and saved lives } \\
\text { (represented by failure token) }\end{array}$ & Remaining money and backlogs \\
\hline Twists & \multicolumn{3}{|c|}{ Common disruptions such as traffic congestions and flooding may be introduced on certain part of the game } \\
\hline
\end{tabular}

retailer would receive the same demand value and location; 3 ) retailers would be able to order goods from any wholesaler; 4) wholesalers would be able to order goods from any distributor; 5) port has two dedicated warehouse locations and the delivery will start from these two locations; and 6) the players are able to consolidate the shipments from two or more orders.

\subsection{Companion Digital Application}

From our first interactive session, we noted some improvements were needed to maximize the players' experience, such as in auto-tracking and graphical presentation of players' actions. These improvements may help to disseminate certain concepts better. For example, by producing a graph at the end of the game session, it may help to explain the bullwhip effect more effectively and help the players to review their decisions throughout the game and how it had affected the whole supply chain performance. In addition to that, several scenarios, such as humanitarian and urban logistics scenarios, may require some complex steps and calculations to determine the best location for the warehouse. It can be very timeconsuming and prone to human error if it is to be done manually.

Based on the above improvement needs, we develop a digital companion application. It is designed not only to assist in complex calculation and display information, but also to guide the players during the game, support the game master (especially the non-experience game master) and record the player's actions and decisions during the game. We believe that with the companion app, the gameplay can be more interactive and lively, 
not only between players but also between the game and the players.

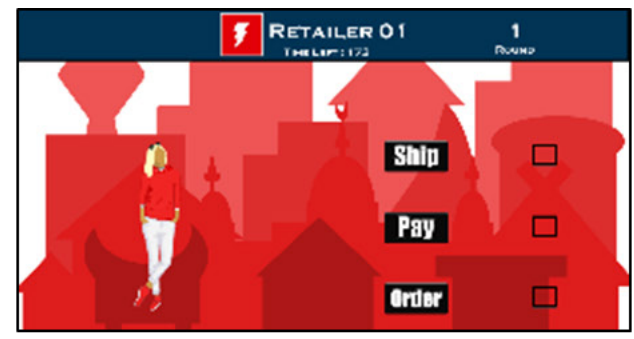

Step-by-step and turn-by-turn play
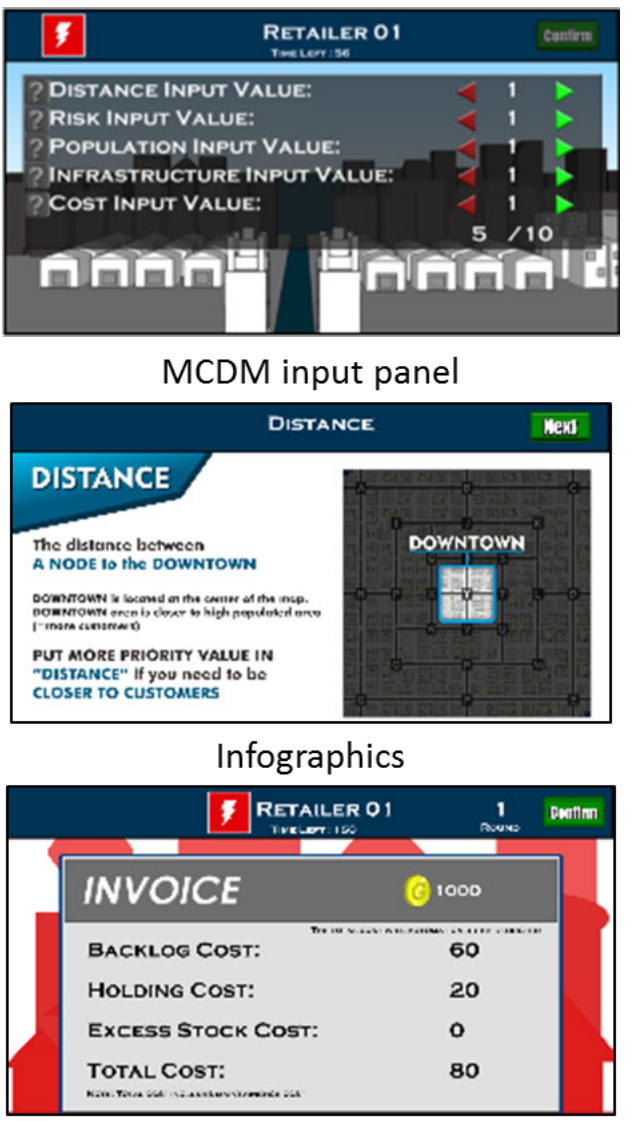

Invoice Panel

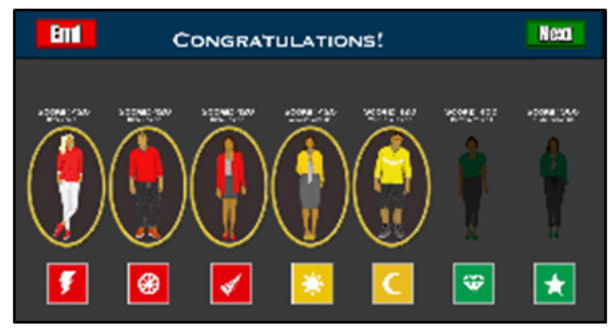

Winner's Panel

Figure 4. Examples of the Companion App Interfaces

The companion app is developed as desktop and mobile application. Several interfaces of the companion app are shown in Figure 4. Ideally, the companion app should be provided to all the players, downloadable for their digital devices. The features of the companion app include:

- Provides step-by-step, turn-by-turn play instructions to the players

- Serves as timekeeper for each player. Failing to keep to the time, the app will assume that no action is required from the player and ends the player's turn

- Captures the transaction inputs from the players and displays them as graphs at the end of the game

- Auto-generates a list of the most suitable locations for the player to choose based on the players' input for the MCDM (for scenarios that use MCDM)

- Provides a function to randomize the congestion locations for each round

- Provides infographics on the different criteria available for the MCDM

- Auto-deducts the cost incurred by each player and presenting its breakdown cost at each turn

- Auto-generates the winner(s) at the end of the game

\section{Evaluation Method}

To evaluate the effectiveness of ThinkLog, we conducted four interactive sessions with senior government officials and supply chain specialists as part of a three-day workshop in SCM. The sessions were held in different cities in Indonesia from August 2016 to April 2018 with different players for each session. Different sessions were played in different ThinkLog scenarios with or without the companion app. Summary of the sessions played is presented in Table 4.

In each session, we divided the players into small groups of eight to ten players where each group would have a mixed composition of players with different background. During the game session, the players were able to interact and discuss with the game masters and other players. Examples of that interaction without and with companion app are shown in Figure 5 and Figure 6 respectively.

We consider Session 1 as a trial session to measure the players' acceptance. For this session, we focused on observing the players' interaction and collecting their sentiments toward the game. In the subsequent sessions, we gathered more feedbacks from the players as well as from the game masters. These include players' sentiment, game experience, learning objective and feedback for companion app. Since the interactive sessions were run under different experimental conditions (i.e. using different scenario, different location and different game masters), we decided to treat the feedback from each session separately.

\subsection{Sentiment Analysis}

To gather the players' sentiments toward the game, we asked the players to provide their comments in an open-ended question. We then applied sentiment analysis method in R to evaluate these comments. Sentiment analysis has been widely used to study opinions, sentiments and emotions expressed in texts to identify positive or negative opinions based on a set of positive and negative lexicon [61]. 
L. William et al. / Advances in Science, Technology and Engineering Systems Journal Vol. 3, No. 4, 99-111 (2018)

Table 4. Summary of the Interactive Sessions

\begin{tabular}{|c|c|c|c|c|c|c|c|}
\hline \multirow{2}{*}{$\begin{array}{l}\text { Interactive } \\
\text { Session }\end{array}$} & \multirow[b]{2}{*}{ Period } & \multirow[b]{2}{*}{ Location } & \multirow{2}{*}{$\begin{array}{l}\text { Numbe } \\
\text { r of } \\
\text { players }\end{array}$} & \multirow{2}{*}{$\begin{array}{c}\text { Using } \\
\text { companion } \\
\text { app }\end{array}$} & \multirow{2}{*}{$\begin{array}{l}\text { The scenario } \\
\text { played }\end{array}$} & \multicolumn{2}{|c|}{ Feedback gathered } \\
\hline & & & & & & $\begin{array}{c}\text { Players } \\
{[\text { feedback(\#valid responses)] }}\end{array}$ & $\begin{array}{l}\text { Game } \\
\text { Masters }\end{array}$ \\
\hline 1 & $\begin{array}{l}\text { August } \\
2016\end{array}$ & Jakarta & 45 & No & Basic & - Players' sentiment (13) & - \\
\hline 2 & $\begin{array}{l}\text { May } \\
2017\end{array}$ & Bandung & 63 & No & Humanitarian & $\begin{array}{ll}- & \text { Players' sentiment (15) } \\
\text { - } & \text { Game experience (34) } \\
\text { - } & \text { Learning objective } \\
& \text { evaluation (34) }\end{array}$ & - \\
\hline 3 & $\begin{array}{l}\text { Novemb } \\
\text { er } 2017\end{array}$ & Makassar & 54 & Yes & E-Commerce & $\begin{array}{ll}\text { - } & \text { Players' sentiment (13) } \\
\text { - } & \text { Game experience (28) } \\
\text { - } & \text { Learning objective } \\
& \text { evaluation (28) } \\
\text { - } & \text { Companion app (28) }\end{array}$ & $\begin{array}{l}\text { companion } \\
\text { app }\end{array}$ \\
\hline 4 & $\begin{array}{l}\text { May } \\
2018\end{array}$ & Yogyakarta & 44 & Yes & E-Commerce & $\begin{array}{ll}\text { - } & \text { Players' sentiment (20) } \\
\text { - } & \text { Game experience (25) } \\
\text { - } & \text { Learning objective } \\
& \text { evaluation (33) } \\
\text { - } & \text { Companion app (33) }\end{array}$ & $\begin{array}{l}\text { companion } \\
\text { app }\end{array}$ \\
\hline
\end{tabular}

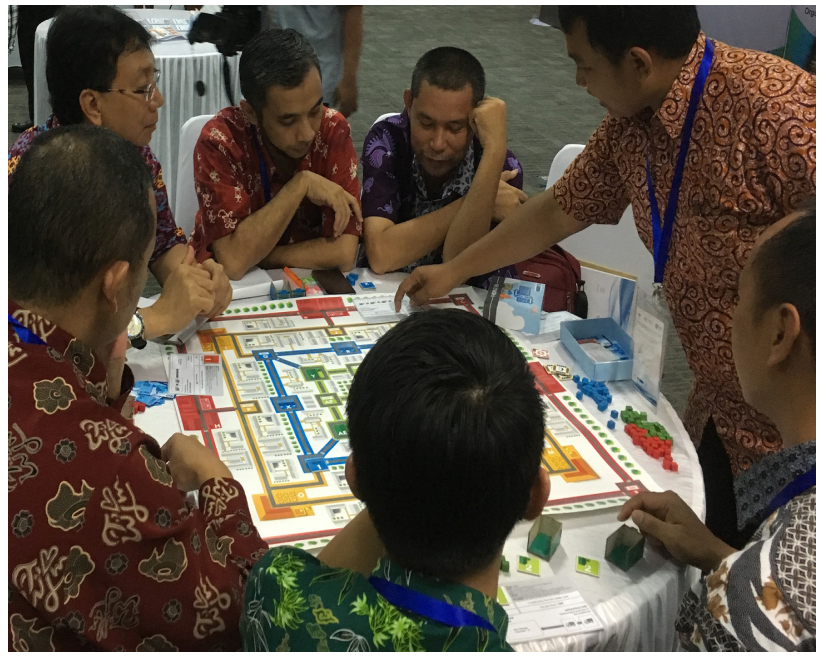

Figure 5. Interactions between the players without companion app

Due to limited positive and negative lexicon database in Bahasa Indonesia, for this study, we used English positive and negative lexicon database $[62,63]$. Before applying the sentiment analysis method, we translated the comments/feedback in English. The survey responses and sentiment analysis score are shown in Figure 7. The result shows that the average sentiment score is above 0 . This indicates positive sentiments toward the game.

\subsection{Game Experience}

We further evaluated the players' game experience in session 2 to 4 . We developed a questionnaire comprising 9 questions focuses on four experience categories, namely: positive, negative, flow, and learning experience. Flow experience is defined as a total engagement in the game that motives the players to win the game by achieving new skills and understanding new concepts voluntarily [64], while learning experience is defined as an ability of the game to transfer its learning objectives to the players [65]. www.astesj.com
The questionnaire used the 4-point Likert scale (4=strongly agrees, $1=$ strongly disagrees). Summary of the responses is shown in Figure 8 .

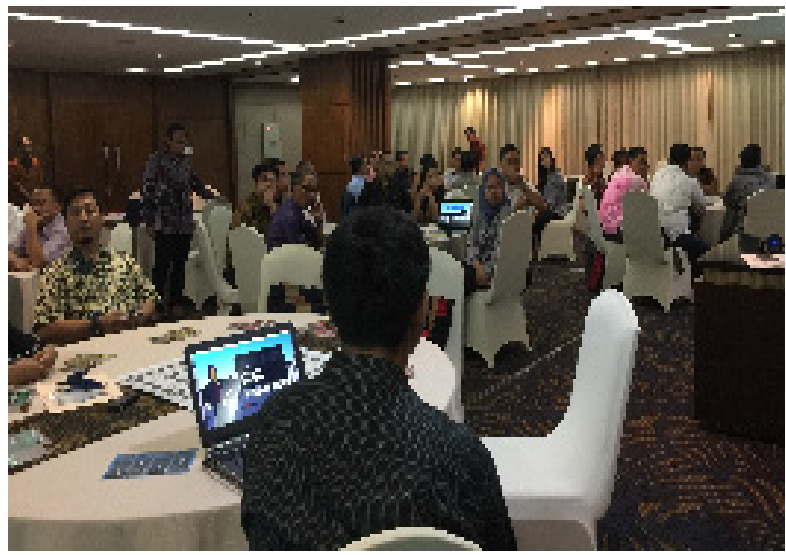

Figure 6. Interactions between the players with companion app

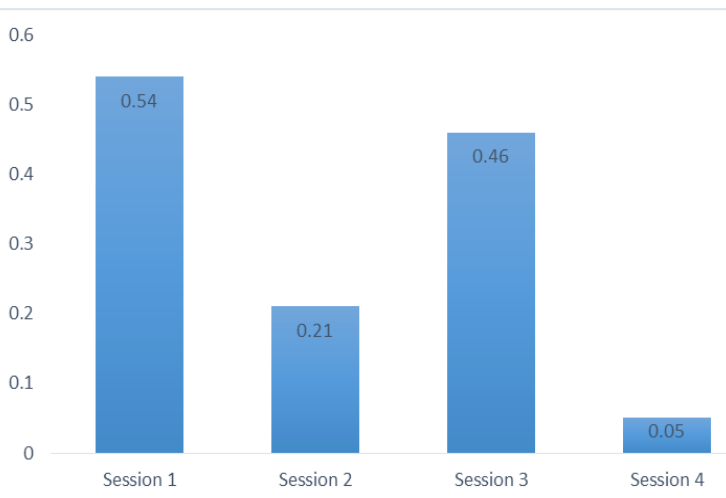

$*=$ score $<0$ represents negative opinion, score $=0$ represents neutral opinion and score $>0$ represents positive opinion

Figure 7. The Players' Sentiment Analysis Score 


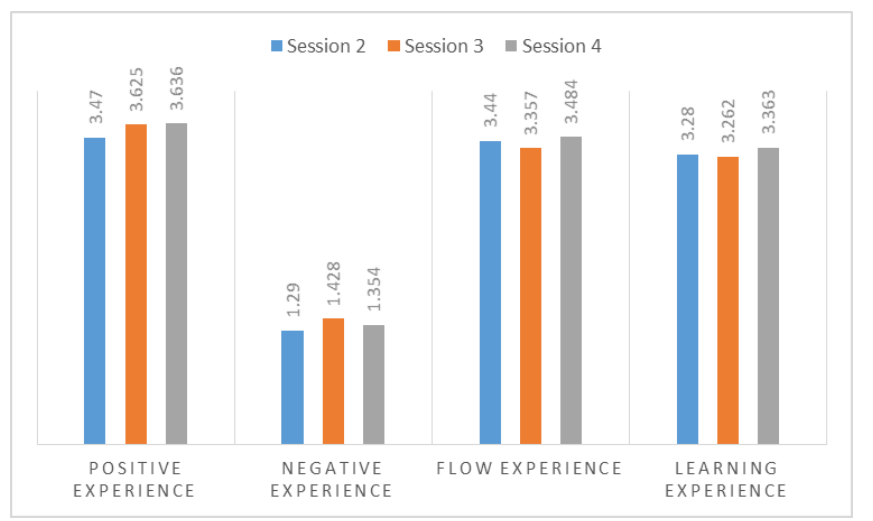

Figure 8. The Players' Overall Game Experience

Figure 8 shows that the average score for two experience categories (positive experience and flow experience) is above 3.3 and the average score for negative experience is below 1.5 for all the game sessions. It indicates that the players have a good experience with the game. For the learning experience, the result shows that the average score is above 3.2 which suggests that the players are able to understand the learning objectives.

\subsection{Learning Objective}

The learning objective is evaluated in the sessions 2 to 4 . Session 2 used the humanitarian logistics scenario, while session 3 and 4 used the urban logistics scenario. The intended learning objectives for these two scenarios are described in Table 3 . These intended learning objectives are to be evaluated against the learning points from the players' perspective.

In session 2, we collected the players' feedback by asking each group of players to list down learning points from the game after they have completed the game. A sample of those lists is shown in Figure 9. In this figure, the players mentioned that their learning points from the game were understanding criteria for determining the location of warehouse/distribution center for relief supply stocks in humanitarian logistics. Those criteria are distance, disaster location, congestions, infrastructure and maintenance cost.

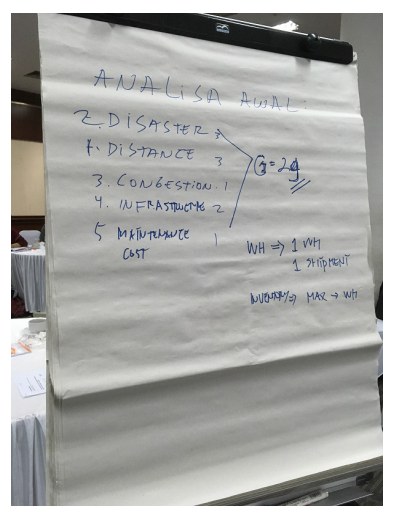

Figure 9. Sample of poster for the players' learning points

The summary of the learning points from the players' perspective in session 2 is as follows:

1. There are a lot of criteria to consider when determining the location of warehouse/distribution center, such as distance to the demand area, congestion, access to infrastructure and cost.
2. The decision makers need to consider some trade-off between those criteria.

3. Communication and coordination are essential to fulfil the demand effectively and efficiently.

These learning points are aligned with the intended learning objectives for humanitarian scenario. In session 3 and 4, we gathered the players' learning points individually. Each player was able to list down one or more learning points. Since we were playing the same scenario in these two sessions, we combined the players' learning points and summarized it in Table 5. From the result, we learnt that the players' learning points are aligned with the intended learning objectives for urban logistics.

\subsection{Feedback on Companion App}

The companion app was first introduced at interactive session 3 and 4 . We gathered feedbacks on the companion app from the players and game masters. For the players, we asked them to evaluate the companion app usefulness in two criteria, namely: helping the players to understand the rule of the game and helping the players to learn about SCM concepts and used a 4-point Likert scale (4=strongly agrees, $1=$ strongly disagrees) to evaluate the criteria. We received 61 valid responses from interactive session 3 and 4. The average score for both criteria is above 3 (3.1 for helping the players to understand the rule and 3.2 for helping the players to learn). It indicates the companion app was well received by the players and it helps with the understanding and learning of the supply chain concepts embedded in the game.

Table 5. Learning Points absorb by the Players in the Third and Fourth Sessions

\begin{tabular}{|l|c|}
\hline \multicolumn{1}{|c|}{ Learning Points } & $\begin{array}{c}\text { Number } \\
\text { of Players }\end{array}$ \\
\hline Importance of warehouse location & 24 \\
\hline Warehouse selection criteria & 11 \\
\hline Order planning and fulfillment & 10 \\
\hline Stakeholders' coordination & 8 \\
\hline Inventory management & 6 \\
\hline Supply chain strategy and management & 6 \\
\hline Warehouse and route optimization & 5 \\
\hline Cost management & 5 \\
\hline Demand forecasting & 3 \\
\hline Communication & 3 \\
\hline Simulation & 1 \\
\hline Supply chain risk & 1 \\
\hline
\end{tabular}

To gather feedbacks from the game masters, we conducted group discussions after the game sessions were completed. From the discussions, we learnt that the companion app is able to speed up and smoothen the game process, but the interface may need to be improved especially for small screen devices. The information shown in the companion app may also need to be filtered or rearranged to avoid information overload that would confuse the players.

\section{Incorporating ThinkLog into Supply Chain Courses}

With its expandable capability, ThinkLog has great potential to be incorporated into supply chain courses with large number of students. ThinkLog scenario can be adjusted to fit in different 


\section{William et al. / Advances in Science, Technology and Engineering Systems Journal Vol. 3, No. 4, $99-111$ (2018)}

courses. For example, the basic scenario is suitable to provide an introduction of SCM, while the humanitarian logistics scenario is suitable for more advance courses or special topics in SCM.

However, there are several challenges to incorporate ThinkLog in courses, especially for classes with a large number of students. Firstly, board game is usually played in small groups to encourage interaction within the group itself [66]. With limited number of game resources (i.e. boards and game masters), it may be impossible to divide large number of students into smaller groups. Secondly, it would be difficult to maintain the level of experience from all the students because the lecturer may not be able to engage with all of the students. Hence, it would be difficult for the students to relate their game experience with the course material.

To mitigate these challenges, we adjust the setup and components of ThinkLog as follows.

1. Group formation. The students are divided in two competing groups. Each group would have its own board. Within each group, students are equally divided to take a particular role (i.e. manufacturer, distributor, wholesaler, and retailer) in the game.

2. Main board. Instead of using real board game, a digital board, projected on the big screen is used to improve visibility for all the students.

3. Demand card. Demand card will be randomly generated using the companion app and shown on the big screen.

4. Game Master. The course lecturer would replace the role of the game master.

5. Companion app. The app would help to keep track of the goods' movement and show it on the digital screen. Virtual money is also used to replace the "game" money.

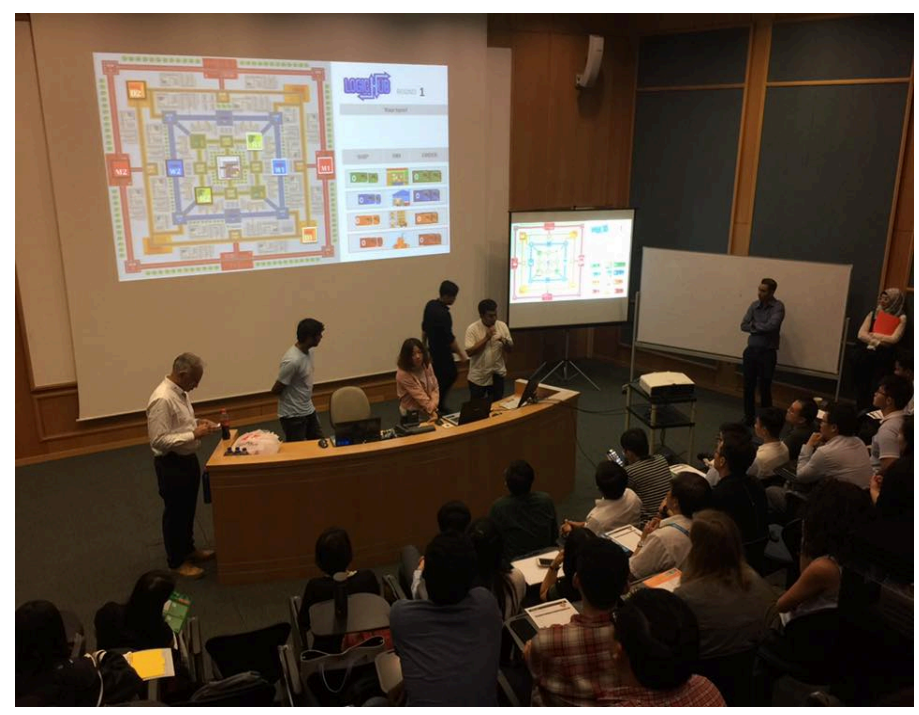

Figure 10. ThinkLog session in a supply chain course in National University of Singapore

We applied these adjustments (with the exception of the Companion app) and tested it on one supply chain course for master students in the National University of Singapore. The class was conducted on August 2017 and attended by 90 students from various backgrounds. Most of the students had background knowledge about SCM. During the game session, we observed that the students were able to discuss within their group and able to raise questions to the lecturer. An example of that interaction is shown in Figure 10.

Based on our observation and discussion with some of the students after the game session, we conclude that the students enjoy the game and highly accept it as part of their course. It's also apparent that the game helps them to understand about the course content better by applying it in the simulated environment within the game.

\section{Summary and Future Work}

In this paper, we focus our study on developing and evaluating an expandable board game, named ThinkLog, as an interactive tool to facilitate learning in Supply Chain Management (SCM). There are four main components in ThinkLog, namely: main board, demand card, gameplay and game master. One unique feature in ThinkLog is that this game can be extended to generate different scenarios for various concepts in SCM without changing the basic game structure. The gameplay can be adjusted to include various scenarios for different learning objectives. To date, we have extended the ThinkLog basic scenario to include two other SCM concepts, namely: humanitarian and urban logistics.

Four interactive sessions as part of three-day SCM workshops were conducted to evaluate ThinkLog. We use different scenarios for each session. Based on our observation, survey and sentiment analysis of the interactive sessions, we learnt that ThinkLog is highly accepted by the players to deepen their understanding of SCM concepts. The result of the learning objective evaluation in sessions 2, 3 and 4 also confirms that the players were able to absorb the learning objectives of the game regardless of the scenario played in the sessions. We also tested our proposed game in a big class environment as part of a supply chain course at the National University of Singapore. The acceptance and learning objective evaluation of the players resonates throughout the game session.

Nonetheless, we see four possible extensions that we would like to study in the near future. First, we would like to test our game in wider audiences and incorporate the game in different supply chain management courses. Further adjustment to the game setup may be needed to cater for different class environment. Second, we would like to embed more scenarios into the game such as healthcare logistics. We may also want to introduce supply chain credibility concept where each role or player would have its own rating or random rating to describe actual distribution processes. It would enrich the game as a platform for learning SCM concepts. Third, we would like to develop a more comprehensive evaluation method to measure the learning outcome of the game. It may include having a third party team to objectively evaluate the players' learning points and compare it with the intended learning objectives of the game. Last but not least, we would like to conduct comprehensive data analysis for each game session to further understand the players' behavior and their actions. For example, the data captured from companion app would help to indicate whether the time allocated for the game session is sufficient or if there is a correlation between the players' background knowledge and the decisions made.

\section{Conflict of Interest}

The authors declare no conflict of interest related to this paper. 


\section{Acknowledgment}

The work is part of solutions/case studies developed as part of "Temasek Foundation International - National University of Singapore Urban Transportation Management Programme in Indonesia" programme. It is supported by Temasek Foundation International and Coordinating Ministry for Economic Affairs of Indonesia.

\section{References}

[1] Lindawati, E. Nugroho, R. Fredericco, Z. Abdul Rahim and R. de Souza, "ThinkLog: Interactive Learning for Supply Chain Management," in IEEE 6th International Conference on Teaching, Assessment, and Learning for Engineering (TALE), Hong Kong, 2017.

[2] S. Tobias, J. Fletcher and A. Wind, "Game-based learning," in Handbook of research on educational communications and technology, New York, Springer, 2014, pp. 485-503.

[3] M. Ma, A. Oikonomou and L. Jain, "Innovations in Serious Games for Future Learning," in Serious Games and Edutainment Applications, London, Springer, 2011, pp. 3-7.

[4] T. Susi, M. Johannesson and P. Backlund, "Serious games: An overview," Technical Report, School of Humanities and Informatics, University of Skövde, Skövde, Sweden, 2007.

[5] S. de Freitas and F. Liarokapis, "Serious Games: A New Paradigm for Education?," in Serious Games and Edutainment Applications, London, Springer, 2011, pp. 9-21.

[6] J. Riedel and J. Hauge, "State of the art of serious games for business and industry," in Concurrent Enterprising (ICE), 2011 17th International Conference, 2011.

[7] J. Breuer and G. Bente, "Why so serious? On the Relation of Serious Games and Learning," Journal for Computer Game Culture, vol. 4, no. 1, pp. 7-24, 2010.

[8] M. Garcia-Ruiz, J. Tashiro, B. Kapralos and M. Martin, "Crouching Tangents, Hidden Danger: Assessing Development of Dangerous Misconceptions within Serious Games for Healthcare Education," in Gaming and Simulations: Concepts, Methodologies, Tools and Applications, Hershey, PA, Information Resources Management Association, 2011, pp. 1712-1749.

[9] S. de Freitas and S. Jarvis, "Towards a development approach for serious games," in Games-based learning advancements for multi-sensory humancomputer interfaces: Techniques and effective practices, T. Connolly, M. Stansfield and E. Boyle, Eds., Hershey, PA, IGI Global, 2008, pp. 215-231.

[10] M. Graafland, J. Schraagen and M. Schijven, "Systematic review of serious games for medical education and surgical skills training," British Journal of Surgery, vol. 99, no. 10, pp. 1322-1330, 2012.

[11] C. Lim and H. Jung, "A study on the military Serious Game," Advanced Science and Technology Letters, vol. 39, pp. 73-77, 2013.

[12] A. Gómez-Rodríguez, J. González-Moreno, D. Ramos-Valcárcel and L. Vázquez-López, "Modeling serious games using AOSE methodologies," in 11th International Conference on Intelligent Systems Design and Applications (ISDA), IEEE, 53-58, 2011.

[13] J. Sterman, "Modeling Managerial Behaviour: Misperceptions of Feedback in a Dynamic Decesion Making Experiment," Management Science, vol. 35, no. 3, pp. 321-339, 1989.

[14] F. a. S. R. Chen, "The stationary beer game," Production and Operations Management, vol. 9, no. 1, pp. 19-30, 2000.

[15] E. Anderson and D. Morrice, "A Simulation Game for Teaching ServiceOriented Supply Chain Management: Does Information Sharing Help Managers with Service Capacity Decision?," Production and Operations Management, vol. 9, no. 1, pp. 40-55, 2000.

[16] S. van Houten, A. Verbraeck, S. Boyson and T. Corsi, "Training for today's supply chains: an introduction to the distributor game," in The 37th Winter Simulation Conference, 2005.

[17] T. Corsi, S. Boyson, A. Verbraeck, S. Van Houten, C. Han and J. Macdonald, "The real-time global supply chain game: New educational tool for developing supply chain management professionals," Transportation Journal, vol. 45, no. 3, pp. 61-73, 2006.

[18] L. Rieber, "Seriously considering play: Designing interactive learning environments based on the blending of microworlds, simulations, and games," Educational Technology Research and Development, vol. 44, no. 2, pp. 43-58, 1996.

[19] J. Knight, S. Carly, B. Tregunna, S. Jarvis, R. Smithies, S. de Freitas, K. Mackway-Jones and I. Dunwell, "Serious gaming technology in major incident triage training: A pragmatic controlled trial," Resuscitation Journal, vol. 81, no. 9, pp. 1174-1179, 2010.

[20] H. Hou, "Integrating cluster and sequential analysis to explore learners' flow and behavioral patterns in a simulation game with situated-learning context for science courses: A video-based process exploration," Computers in human behavior, vol. 48, pp. 424-435, 2015.

[21] J. Hamari, D. Shernoff, E. Rowe, B. Coller, J. Asbell-Clarke and T. Edwards, "Challenging games help students learn: An empirical study on engagement, flow and immersion in game-based learning," Computers in Human Behavior, vol. 54, pp. 170-179, 2016.

[22] L. Zhou, Y. Xie, N. Wild and C. Hunt, "Learning and practising supply chain management strategies from a business simulation game: a comprehensive supply chain simulation," in Simulation Conference, 2008, 2008.

[23] K. Katsaliaki, N. Mustafee and S. Kumar, "A game-based approach towards facilitating decision making for perishable products: An example of blood supply chain," Expert Systems with Applications, vol. 41, no. 9, pp. 40434059, 2014.

[24] T. Nilsen, S. Linton and J. Looser, "Motivations for augmented reality gaming," in Game Developers Conference, FUSE 4, New Zealand, 2004.

[25] S. Gobel, "Serious Game Application Examples," in Serious Game: Foundations, Concepts, and Practice, R. Dörner, S. Göbel, W. Effelsberg and J. Wiemeyer, Eds., Darmstadt, Wiesbaden, Springer, 2016, pp. 319405.

[26] R. Dörner, S. Göbel, W. Effelsberg and J. Wiemeyer, Serious games: foundations, concepts and practice, Darmstadt, Wiesbaden: Springer, 2016.

[27] E. Nugroho and A. Hariyadi, "Creative Learning and Research Through Modern Board Game," in Triple Helix 10 th International Conference, Bandung, 2012.

[28] B. Lamey and C. Bristow, "The Game as a Talking Tool: Using a Board Game for Creative Consultation, Engagement and Inclusion," in Creative Education, Teaching and Learning: Creativity, Engagement and the Student Experience, G. Brewer and R. Hogarth, Eds., London, UK, Palgrave Macmillan, 2015, pp. 243-.

[29] J. Zagal, J. Rick and I. Hsi, "Collaborative games: Lessons learned from board games," Simulation \& Gaming, vol. 37, no. 1, pp. 24-40, 2006.

[30] A. d'Astous and K. Gagnon, "An inquiry into the factors that impact on consumer appreciation of a board game.," Journal of Consumer Marketing, vol. 24, no. 2, pp. 80-89, 2007.

[31] M. Grechus and J. Brown, "Comparison of individualized computer game reinforcement versus peer-interactive board game reinforcement on retention of nutrition label knowledge.," Journal of Health Education, vol. 31, no. 3, pp. 138-142, 2000.

[32] J. Lennon and D. Coombs, "The utility of a board game for dengue haemorrhagic fever health education," Health Education, vol. 107, no. 3, pp. 290-306, 2007.

[33] S. Amaro, A. Viggiano, A. Di Costanzo, I. Madeo, A. Viggiano, M. Baccari, E. Marchitelli, M. Raia, E. Viggiano, S. Deepak and M. Monda, "Kaledo, a new educational board-game, gives nutritional rudiments and encourages healthy eating in children: a pilot cluster randomized trial," European journal of pediatrics, vol. 165, no. 9, pp. 630-635, 2006.

[34] W. Bartfay and E. Bartfay, "Promoting health in schools through a board game," Western Journal of Nursing Research, vol. 16, no. 4, pp. 438-446, 1994.

[35] A. Vahed, "The tooth morphology board game: an innovative strategy in tutoring dental technology learners in combating rote learning," in 2nd European Conference on Games Based Learning, 2008.

[36] P. Ogershok and S. Cottrell, "The pediatric board game," Medical Teacher, vol. 26 , no. 6 , pp. 514-517, 2004. 
[37] S. Fukuchi, L. Offutt, J. Sacks and B. Mann, "Teaching a multidisciplinary approach to cancer treatment during surgical clerkship via an interactive board game," The American journal of surgery, vol. 179, no. 4, pp. 337$340,2000$.

[38] I. Mayer, L. Carton, M. de Jong, M. Leijten and E. Dammers, "Gaming the future of an urban network," Futures, vol. 36, no. 3, pp. 311-333, 2004.

[39] E. Speelman, L. García-Barrios, J. Groot and P. Tittonell, "Gaming for smallholder participation in the design of more sustainable agricultural landscapes," Agricultural Systems, vol. 126, pp. 62-75, 2014.

[40] K. Slegers, S. Ruelens, J. Vissers and P. Duysburgh, "Using game principles in ux research: A board game for eliciting future user needs," in 33rd Annual ACM Conference on Human Factors in Computing Systems, 2015.

[41] A. Van Ackere, E. Larsen and J. Morecroft, "Systems thinking and business process redesign: an application to the beer game," European Management Journal, vol. 11, no. 4, pp. 412-423, 1993.

[42] F. Jacobs, "Playing the beer distribution game over the internet," Production and Operations Management, vol. 9, no. 1, pp. 31-39, 2000.

[43] J. Wisner, K. Tan and G. Leong, Principles of supply chain management: A balanced approach, Cengage Learning, 2014.

[44] N. Mustafee and K. Katsaliaki, "The blood supply game," in Winter Simulation Conference 2010, 2010.

[45] D. Simchi-Levi, E. Simchi-Levi and P. Kaminsky, Designing and managing the supply chain: Concepts, strategies, and cases, New York: McGraw-Hill, 1999.

[46] P. Kaminsky and D. Simchi-Levi, "A new computerized beer game: A tool for teaching the value of integrated supply chain management," Global supply chain and technology management, vol. 1, no. 1, pp. 216-225, 1998.

[47] A. Abdul Jabbar and P. Felicia, "Gameplay engagement and learning in game-based learning: A systematic review," Review of Educational Research, vol. 85, no. 4, pp. 740-779, 2015.

[48] M. Holweg and J. Bicheno, "Supply chain simulation - a tool for education, enhancement and endeavour," International Journal of Production Economics, vol. 78, no. 2, pp. 163-175, 2002.

[49] T. Muller, R. Müller, K. Zedel, G. Zomer and M. Engler, "Enhancing awareness on the benefits of supply chain visibility through serious gaming," in Conference on e-Business, e-Services and e-Society, 2015.

[50] D. R. Cruickshank and R. Telfer, "Classroom games and simulations," Theory Into Practice, vol. 19, pp. 75-80, 1980.

[51] M. R. Lepper and D. L. Cordova, "A desire to be taught: Instructional consequences of intrinsic motivation," Motivation and Emotion, vol. 16, pp. 187-208, 1992.

[52] T. W. Malone and M. R. Lepper, "Making learning fun: A taxonomy of intrinsic motivations for learning," in Aptitude, learning and instruction, vol. 3, R. Snow and M. Farr, Eds., Hillsdale, NJ, Erlbaum, 1987, pp. 223253.

[53] R. Rouse, Game design: theory \& practice, Plano, TX: Wordware Publishing, Inc , 2005.

[54] M. J. Hannafin and K. Peck, The design, development and evaluation of instructional software, New York: MacMillan Publishing Company, 1988.

[55] A. Wilson, C. Broadbent, B. McGrath and J. Prescott, "Factors Associated with Player Satisfaction and Educational Value of Serious Games," in Serious Games and Edutainment Applications, Springer, 2017, pp. 513-535.

[56] J. Van Staalduinen and S. de Freitas, "A game-based learning framework: Linking game design and learning," in Learning to play: exploring the future of education with video games, M. Khine, Ed., New York, Peter Lang, 2011, pp. 29-54.

[57] S. M. Alessi and S. R. Trollip, Multimedia for learning: Methods and development, Boston: Allyn and Bacon, 2001.

[58] P. Vincke, "MCDM: Past decade and future trends-A source book of multiple criteria decision making," European Journal of Operational Research, vol. 26, no. 1, pp. 179-780, 1986.

[59] M. Köksalan, J. Wallenius and S. Zionts, "An Early History of Multiple Criteria Decision Making," Journal of Multi-Criteria Decision Analysis, vol. 20, no. 1-2, pp. 87-94, 2013.

[60] G. Timperio, G. Panchal, R. De Souza, M. Goh and A. Samvedi, "Decision making framework for emergency response preparedness: A supply chain resilience approach," in IEEE International Conference on Management of Innovation and Technology (ICMIT), 2016.

[61] G. Miner, J. Elder IV and T. Hill, Practical text mining and statistical analysis for non-structured text data applications, Academic Press, 2012.

[62] M. Hu and B. Liu, "Mining and Summarizing Customer Reviews,," in $A C M$ SIGKDD International Conference on Knowledge Discovery and Data Mining (KDD-2004), Seattle, Washington, USA, 2004.

[63] B. Liu, M. Hu and J. Cheng, "Opinion Observer: Analyzing and Comparing Opinions on the Web," in the 14th International World Wide Web conference (WWW-2005), Chiba, Japan, 2005.

[64] K. Kiili, "Evaluations of an Experiential Gaming Model," An Interdisciplinary Journal on Humans in ICT Enviroments, vol. 2, no. 2, pp. 187-201, 2006.

[65] H. Kelly, "How Games and Simulations Can Help Meet America's Challenges in Science Mathematics and Technology Education," in Serious Game Design and Development: Technologies for Training and Learning, IGI Global, 2010, pp. 117-133.

[66] S. Fukuchi, L. Offutt, J. Sacks and B. Mann, "Teaching a multidisciplinary approach to cancer treatment during surgical clerkship via an interactive board game," The American journal of surgery, vol. 179, no. 4, pp. 337340,2000 . 